\author{
ANETA JUDZIŃSKA \\ Uniwersytet im. Adama Mickiewicza \\ $w$ Poznaniu
}

\title{
(SHE) WOMAN AND (HE) UNIVERSITY. ATTRACTION FATALE OR L'AMOUR RÉCIPROQUE? THE ACADEMIC CAREERS OF WOMEN
}

\begin{abstract}
Judzińska Aneta, (She) Woman and (He) University. Attraction Fatale or L'amour Réciproque? The Academic Careers of Women [(Ona) Kobieta i (On) Uniwersytet. Fatalne zauroczenie czy miłość odwzajemniona? Kariery akademickie kobiet]. Studia Edukacyjne nr 37, 2015, Poznań 2015, pp. 275287. Adam Mickiewicz University Press. ISBN 978-83-232-0000-0. ISSN 1233-6688. DOI: $10.14746 /$ se.2015.37.16
\end{abstract}

The phenomenon of insufficient women representation in science and the problem of female academics "disappearing" from careers in the humanities and social sciences is the main area of the author's reflection. The analysis is made within two perspectives: academic and feminist. The first one is organizational and locates reasons for the lack of female academics and postgraduate students in situational and personality factors in women, highlighting the problem of their individual competences and individual choices, between career and family life. The second, feminist/organizational orientation indicates presence of discrimination, with its manifestations in structures of higher and primary/secondary education. They are seen in context of numerous stereotypes and gender prejudices, generated by the essentialist perspective on gender, which influences how women's cognitive abilities are assessed (the case of school mathematical competencies).

Key words: women's academic career, underrepresentation of female academics, self-exclusion, organisational barriers

„While it is true that women are found at all levels of the social space, their chances of access decline as one moves towards the rarest and most sought-after positions" 1 . An cademic career - regardless of the level of its social desirability ${ }^{2}$ - is, in my opinion, perfectly described by the thought of

1 P. Bourdieau, Męska dominacja, Warszawa 2004, p. 109.

2 I will not be discussing here in which of the two groups mentioned by P. Bourdieu the profession of academic teacher and academic career belong. 
P. Bourdieu. Defined by the sociological theory as an expression of social mobility of individuals ${ }^{3}$, possible thanks to "professional work life which include advancement" 4 , it leads to "individual success and satisfaction" (after: Richardson) $)^{5}$. Therefore, assuming a neoliberal view of reality, can we unequivocally state that academic career has a highly individual course, depending on the person's biography and the character of their biological, psychological and cultural competencies? Taking it a step further, can we then get rid of the gender component, treating it as some sort of magna absens? In my opinion it cannot be done. Trajectories of women's professional careers, especially in highly masculinized environments (although, according to some data, it happens also in some feminized ones ${ }^{6}$ ) require a professional analysis, taking into account the whole spectrum of direct and indirect factors. As E.H. McWhirter states ,the larger social forces of racism, sexism, and classism form a context within which the career and educational attainment of women and people of color must be understood"7. In the literature there are several interesting concepts of how to analyze professional careers (including academic ones) in context of gender. Valuable views on its development can be found, among others, in works of G. Hackett \& N.E. Betz (Career Self-Efficacy Theory ${ }^{8}$ ), E.P. Cook, M.J. Heppner \& K.M. O'Brien (Ecological Perspektive ${ }^{9}$ ) and R.W. Lent, S.D. Brown \& G. Hackett (The Social Cognition Career Theory SCCT) ${ }^{10}$.

It seems however, that in public (and everyday) discourse the problem of gender (dis)harmony in professional life is still (un)consciously ignored, remaining in a marginal position in the hierarchy of social issues ${ }^{11}$. We may assume that one of the determining factors here is a "schizophrenic" political transformation, synonymously expressed as the paradoxes of emancipation.

3 A. Cybal-Michalska, Młodzież akademicka a kariera zawodowa, Kraków 2013, p. 36.

${ }^{4}$ W. Patton, M. McMahon, Career Development and Systems Theory: Connecting Theory and Practice, Rotterdam-Boston-Taipei 2014, p. 4.

${ }^{5}$ Ibidem, p. 6.

${ }^{6}$ It refers to the situation in which men still hold the highest positions in feminized professions.

7 E.H. McWhirter, Perceived Barriers to Education and Career: Ethnic and Gender Differences, Journal of Vocational Behavior, 1997, 50, p. 124.

${ }^{8}$ G. Hackett, N.E. Betz, A Self-Efficacy Approach to the Career Development of Women, Journal of Vocational Behavior, 1981, 18.

9 E.P. Cook, M.J. Heppner, K.M. O'Brien, Career development of women of color and white women: Assumptions, conceptualizations, and interventions from an ecological perspective, The Career Development Quarterly, 2002, 20.

10 W. Patton, M. McMahon, Career Development and Systems Theory, p. 101.

${ }^{11}$ Indeed, I often observed that the problem of underrepresentation of female academics is completely unacknowledged, also in the academic circles. 
This schizophrenic reality consists of the two contradictory dimensions: visible - concerning applied rules of gender equality, and hidden - connected with the problem of "invisible barriers" which effectively limit women's ability to move up the career ladder ${ }^{12}$. Therefore, the problem is relatively concealed, just as its past connections with the masculinized professional archetype ${ }^{13}$.

\section{Women's Academic Career - a Fact or an Oxymorone?}

In 1897, near the end of the $19^{\text {th }}$ century, when academic world was still exclusively a male domain, it opened its gates for Polish women. First female students attended Lviv and Cracow universities. It should be noted however, that women's access to university education did not entail allowing them to become professional researchers nor pursue academic careers. As Monika Sulik points out, "it required much effort for women to achieve the position of research assistant (Jagiellonian University in 1907), postdoctoral degree (in 1920) and professorship (in 1929)"14. Undoubtedly, the idea of meritocracy, however sublime in theory (but not free from numerous mistakes, as it preserves social inequality and contributes to the cultural and economic reproduction, among others) which proclaims equality of access and opportunities, plays a part in paving the way to women's careers in professions traditionally (deterministically) ascribed to men. Abandoning the essentialist view of competency measurement to the ideology of "equality in achieving success", unbiased by gender, class or race, "abolished the traditional »exclusion in advance «"15. Education became the basic channel of social mobility and university - one of its key "mechanisms of selection"16.

12 A. Gromkowska-Melosik, Edukacja, kultura i rekonstrukcje kobiecości we wspótczesnej Japonii (ucieczka do/od równości i wolności), [in:] Problemy nierówności społecznej w teorii i praktyce edukacyjnej, eds A. Gromkowska-Melosik, T. Gmerek, Kraków 2008, p. 133-134.

${ }^{13} \mathrm{M}$. Młodożeniec and A. Knapińska reflect upon the gender of Polish research practice, including its historical roots, in an interesting article: Is science still male? The participation of women in scientific research, NAUKA, 2013, 2.

14 M. Sulik, Kobiety w nauce. Podmiotowe i społeczno-kulturowe uwarunkowania, Katowice 2010, p. 48.

${ }^{15}$ A. Gromkowska-Melosik, Indywidualizm, liberalna edukacja i paradoksy emancypacji kobiet, [in:] Problemy nierówności społecznej, p. 79.

16 Z. Melosik, Uniwersytet i spoteczeństwo: dyskursy wolności, wiedzy i władzy, Kraków 2009, p. 106. 


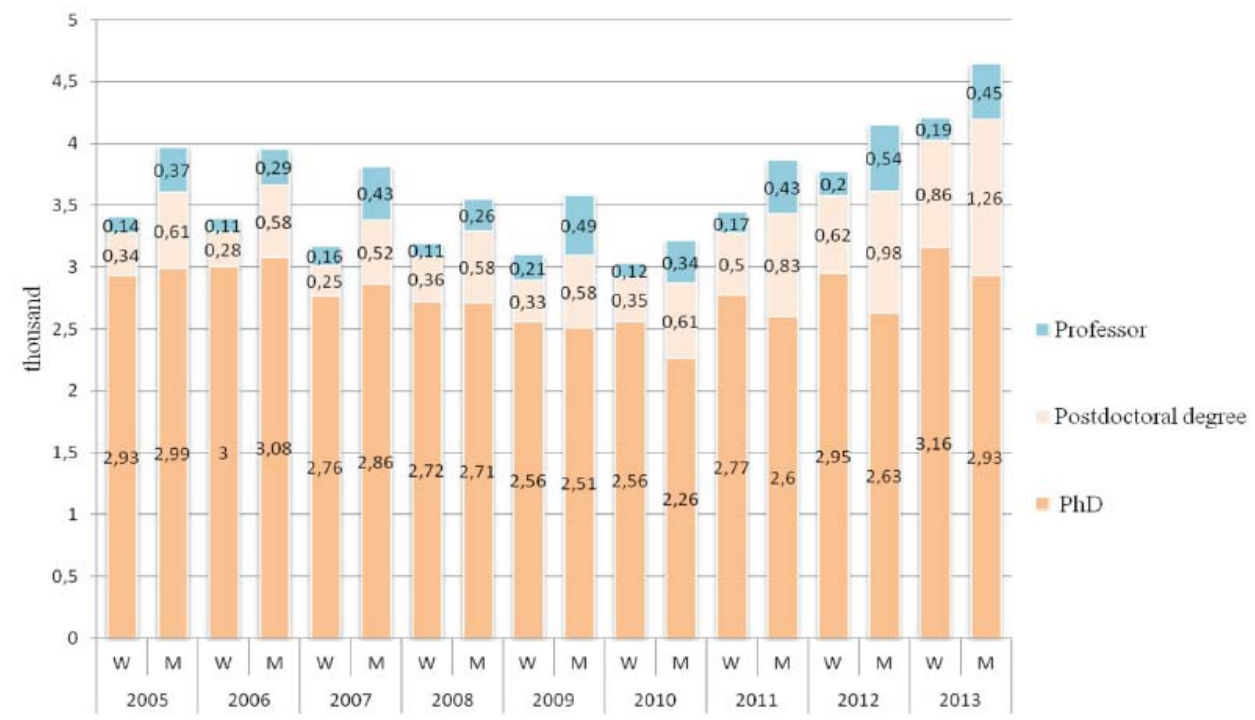

Fig. 1. Awarded degress by sex

(Source: Self-study on the Science and Technology in 2013, GUS, p. 102-103)

However, when analyzing current empirical data, one may get the impression that those academic career paths are significantly more intricate and meandering in case of women than in case of men. The access to academic research, legally guaranteed for both sexes, does not harmonize with empirical distribution of academic promotions, which allows us to conclude that pursuing academic career and taking on the role of a researcher becomes an enormous challenge for women. Reaching the highest levels of university career ladder is still permeated with "gender disharmony". A desire to reach the academic peak costs women a lot more effort, sometimes futile, than choosing some sort of "traditionally" feminine profession.

Data gathered by Central Statistical Office of Poland may serve as empirical evidence here. It contains the percentage of academic degrees and titles awarded to women and men between the years 2005 and 2013. Statistical charts show that for the $\mathrm{PhD}$ degree the distribution of gender is either similar or even slightly higher for women since 2008. The phenomenon of disappearance of female researchers from the academic career path becomes visible only among post-docs and professors. It is clearly evident in the following results: until 2010 the number of women with post-doctoral degrees was nearly half the amount of men who shared this position on the academic 
ladder. Since 2010 this number has dropped slightly in favor of women, but has not led to gender equality in this case. At the level of professor's degree we may see even more significant gender disproportions, as the number of women with this title is almost two times smaller than of men. Let's note that these tendencies did not change between the year 2005 and 2013.

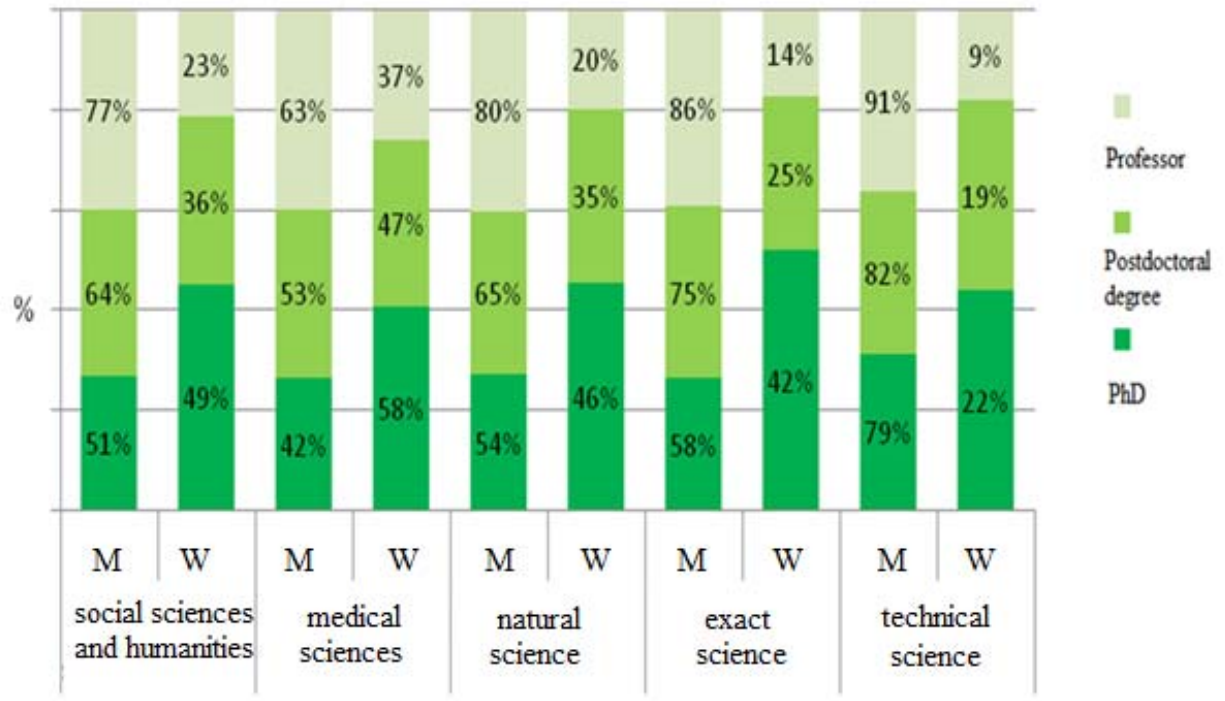

Fig. 2. Distribution of academic degrees and titles among men and women in particular study Fields

(Sorce: Self-study on the Polish Science Database, „Nauka Polska” [Access in April 2015])

The second chart contains results which vary in terms of gender as well as subsequent research disciplines. They were presented in the form of comparisons between male and female researchers with the same academic degree/ title. The aforementioned statistics confirm the phenomenon shown at the previous chart - the underrepresentation of women researchers in every academic discipline, which is particularly evident at the level of postdoctoral and professor's level. In addition, it emphasizes those areas of research in which the shortage of women begins from the $\mathrm{PhD}$ level - that is, in science and technology. Therefore, we are dealing here with a particular processual regularity, in which the higher degree or academic title, the less women are represented. Why does it happen? What are the mechanisms that cause women to disappear from the academic environment? 


\section{The Underrepresentation of Female Academics - Searching for Causes of Gender Inequality}

In order to find causes of this disappearance I used the two-faceted model by Aleksandra Derra which encourages the researcher to consider so called gender issue in science from two points of view: academic and feminist. The former is looking for causes of gender disharmony in situational and personality factors in women themselves, the latter - the feminist approach, focuses on organizational factors, generated by the organization itself ${ }^{17}$. According to the author, categories of "»the masculine« and »the feminine « are not rooted in some permanent, universal, unequivocally biological entity, essence, but they were created within historical, contingent processes, which consolidated a certain one-dimensional, homogenous understanding and the role of what is "masculine $«$ and »feminine $« " 18$. A. Derra - rightly, in my opinion - promotes desexualization of cognitive and personal factors (in contrast to the situational ones, such as motherhood!) which determine intellectual potential of academic workers, and she notices that it can help to eliminate stereotypes and prejudices, generated by the essentialist perspective.

While reflecting on the first group of factors, we should mention the phenomenon of self-exclusion of women from the career, studied by the native (A. Gromkowska-Melosik) as well as foreign researchers (C. Leeb, P. Essed et al., S. Grenz et. al.). This phenomenon is very well described by Claudia Leeb, who analyses the presence of women in academia. She stresses that ",self-exclusion shows most clearly the ways that interpellated subject »work themselves" and as such become the "always-already « subject of the ideological structure of the academic institution". In American reality it is particularly significant in case of female researchers from working or middle class ${ }^{19}$. We should emphasize that the depth of this problem reaches early socialization process in which the message girls receive is based on traditional, binary gender values and defines a woman as fragile, incapable of brutal male competition and therefore she can be, nota bene, competent in humanities, but not in science ${ }^{20}$. A. Gromkowska-Melosik calls this phe-

17 A. Derra, KOBIETY (W) NAUCE: Problem płci we wspótczesnej filozofii nauki i w praktyce badawczej, Warszawa 2013, p. 21.

18 Ibidem, p. 27.

${ }^{19}$ C. Leeb, Working Class Women in Elite Academia: A Philosophical Inquiry, Brussels 2004, p. 145.

${ }^{20}$ Cf. E. Zamojska, Równość w kontekstach edukacyjnych. Wybrane aspekty równości w polskich i czeskich podręcznikach szkolnych, Poznań 2010. 
nomenon a restriction of women's identity ${ }^{21}$. An interesting perspective on the question of early educational and environmental factors and their influence on the shape of women's professional careers was offered by the aforementioned researchers: G. Hackett and N. E. Betz. Referring to the key concepts of A. Bandura's social learning theory (precisely the notion of selfefficacy), they created a Self-Efficacy Theory. The base of this theory is built on a presumption that socialization practice has a fundamental meaning for the individual's cognitive judgments, which regulates the level of their sense of self-efficacy ${ }^{22}$. According to the authors: "largely as a result of socialization experiences, women lack strong expectations of personal efficacy in relationship to many career-related behaviors and, thus, fail to fully realize their capabilities and talents in career pursuits" 23 . The importance of the selfefficacy factor in the development of mathematical and scientific competencies was also noticed by the PISA representatives. The research carried out in the year 2006 and then in 2012 revealed significantly lower scores for girls, as compared with boys (bigger disproportions of self-efficacy in mathematics than in sciences), although the main difference between the sexes depended on the type of the task/ problematic situation (boys scored higher in mathematical tasks with gender-stereotypical content ${ }^{24}$ ). A meaningful commentary on the existence of genderless (socialization-related) determinants of mathematical competencies was given by the Secretary-General of the OECD, Angel Gurría, who writes in the introduction to the Report, that:

in the top-performing economies in PISA, such as Shanghai-China, Singapore, Hong Kong-China and Chinese Taipei, girls perform on a par with their male classmates in mathematics and attain higher scores in mathematics than boys in most other countries and economies around the world. As the evidence in the report makes clear, gender disparities in performance do not stem from innate differences in aptitude, but rather from students' attitudes towards learning and their behaviour in school, from how they choose to spend their leisure time, and from the confidence they have - or do not have - in their own abilities as students. In fact, the report shows that the gender gap in literacy proficiency narrows considerably - and even disappears in some countries - among young men and women in their late teens and $20 \mathrm{~s}^{25}$.

21 A. Gromkowska-Melosik, Edukacja i (nie)równość społeczna kobiet: studium dynamiki dostępu, Kraków 2011, p. 489.

${ }^{22}$ N.E. Betz, G. Hackett, Career Self-Efficacy Theory: Back to the Future, Journal of Career Assessment, 2006, 14(1), p. 4.

${ }^{23}$ G. Hackett, N.E. Betz, A Self-Efficacy Approach to the Career, p. 326.

${ }_{24}$ The $\mathrm{ABC}$ of Gender Equality in Education Aptitude, Behaviour, Confidence, OECD 2015, p. 3, http://www.oecd.org/pisa/keyfindings/pisa-2012-results-gender-eng.pdf, [Accessed: 26.07 .2015$]$.

${ }^{25}$ Ibidem. 
In conclusion to this section, I would like to stress - according to the results of mathematical tasks - that from 65 countries, in 22 of them (including Poland) no statistical differences were found between the sexes. Moreover, in 5 countries (Jordan, Qatar, Thailand, Malaysia and Iceland) girls' mathematical competencies turned out to be higher ${ }^{26}$.

The phenomenon of self-exclusion from the career does not always stem from the limitations of identity, seen in context of low self-efficacy and low self-esteem. In her monograph "Education and Social (In)Equality of Women: A Study of the Dynamics of Access", A. Gromkowska-Melosik exposes another factor, which she calls women's individual choices ${ }^{27}$. It boils down to the elementary conflict between professional career and family life, which is solved by abandoning work-related aspirations to motherhood and family 28 . Resignation from gaining professional experience in order to embody the essence of womanhood takes form of trying to fulfill "new and exacting standards of motherhood", mentioned in the 50's by A. Myrdal i V. Klein in their book "Women's Two Roles: Home and Work"29. Contemporary researchers make an assumption that motherhood becomes a turning point in a woman's professional career. By taking form of an internal imperative, it becomes - metaphorically speaking - the mythological Oracle of Delphi, revealing the shape of the future. It does not require a dispassionate, "coldhearted calculation", it is rather a psychological act of will, created in a woman's mind by the presence of such circumstances as the number of her existing children, the women's age when she had her first baby, the birth order of children and mother's readiness to work outside the home ${ }^{30}$.

The second group of factors revolves around organizational barriers generated by the organization itself. Therefore it is opposed to the factors mentioned above, as the source of problems here is situated outside, not within an individual. It is worth to remind the notion of "vocational stuckness", analyzed by R. Kanter. He describes this phenomenon as based on the belief that career is processual, which means that the category of change-

26 Program Międzynarodowej Oceny Umiejętności Uczniów OECD PISA, PISA 2012, p. 48-49, http://www.ibe.edu.pl/images/prasa/PISA-2012-raport_krajowy.pdf, [Accessed: 26.07.2015].

27 A. Gromkowska-Melosik, Edukacja i (nie)równość społeczna kobiet, p. 238.

${ }^{28}$ I wrote more on the problem of women's individual choices between professional career and family in the article: A. Judzińska, Womanhood-contemporary paradoxes of equality and exclusion, Journal of Gender and Power, 2014, 2(2), p. 140-146.

${ }^{29}$ A. Myrdal, V. Klein, Women's Two Roles: Home and Work, London 1956, p. 125.

30 S.D. Brown, R.W. Lent, Career Development and Counseling: Putting Theory and Research to Work, New Jersey 2013, https:// books.google.pl/books?id=3AEnri4bwWAC\&pg=PT196\&dq= women+career+or+motherhood\&hl=pl\&sa=X\&ved=0CCQQ6AEwATgUahUKEwivztnS6_ vGAhVCCdsKHSSYAUE\#v=snippet\&q=\%20U.S.\%20Census\&f=false, [Accessed: 27.07.2015]. 
ability is fundamentally included in its definition. Therefore, a path of a career may look like an ever-shifting kaleidoscope, shaped by favorable as well as adverse conditions. This mosaic of professional experiences does not, as a matter of fact, threaten the equality and subjectivity of an individual. The final arbiter, responsible for the shape and keeping professional aspirations via regulation of "ambition and drive" of the workers, is the university. Depending on its openness or closeness, it can support or hinder personal growth of female academics ${ }^{31}$.

While acknowledging diversity as well as extraordinary conceptual productivity in defining barriers of stratification, I will limit my reflections to several key concepts. Firstly, I will describe the notion of a glass ceiling, one of the most popular among the mechanisms of stratification. In academic nomenclature it is defined as "the structural barrier (...) preventing able women from entering the most senior and powerful positions" 32 . This is how one of the researchers explains the glass ceiling phenomenon: "The glass ceiling is all to real, thus I think women must not only achieve technically as men do, but figure out how to make the system work for them, which is different from the entitlement mode of career paths for men"33. The presence of invisible barriers, effectively restricting women's promotion within academy ${ }^{34}$, became a focus of attention of the European Statistical Office, which developed a Glass Ceiling Index, measuring professional chances of women compared to men. The interpretation is made as follows: a result which equals 1 means there are no differences between men and women in terms of their professional success. In a situation when the result exceeds 1 , it means that women are underrepresented in the highest academic positions, and when it is less than 1, it indicates their overrepresentation. The latest results for Poland were calculated in 2008 and the GCI equaled $1.8^{35}$.

An interesting counter-proposal to the glass ceiling is the concept of the stone floor, analyzed by D. Mason and N. Jewson (after: E. Hannah et. al). It is fundamentally similar to the sticky floor theory, as both express the idea

31 S.T. Gregory, Black Women in the Academy: The Secrets to Success and Achievement, Lanham 1999, p. 100.

32 Ch. Heward, Women and Careers in Higher Education: What is the Problem? Christine Hewards, [in:] Breaking Boundaries: Women in Higher Education, eds. L. Morley, V. Walsh, London 2005, p. 13.

33 S.V. Rosser, The Science Glass Ceiling: Academic Women Scientists and the Struggle to Succeed, London 2004, p. 42.

${ }^{34}$ L. Brannon, Psychologia rodzaju. Kobiety i mężczyźni: podobni czy różni, Gdańsk 2002, p. 395.

35 She Figures 2012, Statistics and Indicators and Innovation, Gender in Research, http:/ /ec.europa.eu/research/science-society/document_library/pdf_06/she-figures2012_en.pdf, [Accessed: 27.07.2015]. 
of the lack of space for career development ${ }^{36}$. In this approach, women are assigned to certain groups of less prestigious and less paid professions. In practice, this means that women do more teaching than research, as compared to men. They also appear more often in those areas of research which are perceived less prestigious. Moreover, the majority of them work in an underfunded public sector ${ }^{37}$. Additionally, the metaphor of the stone floor is expressed in the coldness of stones, which, according to Caplan (after: Hannah et al.), reflect the attitude of men towards their female colleagues in their interpersonal relations ${ }^{38}$.

I shall also mention the phenomenon called a vanish box, which implies that women disappear from the academic world like a person in a magician's closet. "In the classic magic trick, the audience sees a person who hides in a closet and the door is closed behind them. When the door is opened, the closet appears to be empty. The magician closes the door then, and opens it again and the audience can see the formerly invisible person"39. A similar thing happens to female academics - they disappear from the academic world in an illusory manner. They can be seen in the surrounding sectors, for example in the transfer of technology or enterprise ${ }^{40}$. Interesting data on the disappearance of female academics from the STEM ${ }^{41}$ area is presented by E. Yost et al. According to the researchers, the main reason why women leave the scientific world is motherhood. Achieving a relatively stable academic position $(\mathrm{PhD})$ is synchronized with the peak of their reproductive life. In consequence, they often make a decision to leave, "signaling a brain drain in academia", which often leads to the "disadvantage in their careers when women then choose to re-enter the workforce" 42 .

While presenting the organizational barriers which determine the form of academic promotion of women, we should also mention distorted interpersonal relations between female academic, called the short-ladder phenomenon, or, synonymously, the queen bee syndrome. In a wider context, this phenomenon is explained as a "conscious acceptance of masculine iden-

${ }^{36}$ E. Hannah, S. Vethamany-Globus, L. Pau, Women in the Canadian Academic Tundra: Challenging the Chill, Canada 2002, p. 8.

${ }_{37}$ M. Młodożeniec, A. Knapińska, Czy nauka wciąż ma męska płeć? p. 55-58.

${ }^{38}$ E. Hannah, S. Vethamany-Globus, L. Pau, Women in the Canadian Academic Tundra, p. 8.

${ }^{39}$ M. Młodożeniec, A. Knapińska, Czy nauka wciąż ma męską płeć? p. 55.

${ }^{40}$ Ibidem, p. 55-58.

${ }^{41}$ Academic disciplines of science, technology, engineering and mathematics.

42 E. Yost et al., Understanding the Links between Mentoring and Self-Efficacy in the New Generation of Women STEM Scholars, [in:] Women in Engineering, Science and Technology: Education and Career Challenges, eds. A. Cater-Steel, E. Cater, New York 2010, p. 100. 
tity and rejection of traditional feminine identity features" 43 . As Anna Titkow points out in her research on careers, women who achieve success in masculinized professions, usually use masculine behavioral standards, expressing their solidarity with the opposite sex ${ }^{44}$. The identification with traditional masculine traits, highly valued in our culture, becomes an ennobling activity, in the professional (at the helm of men's power) as well as social context (such women are appreciated by male professionals and belong to their elite). Depreciation of traditional womanhood is accompanied by rejection of all concepts of gender stratification mechanisms which function in the particular organization. Moreover, the lack of promotion among female coworkers is attributed to individual factors, such as personality deficits 45 .

In conclusion, statistical data shows that the so called "gender equality policy" did not break all barriers of gender discrimination and processes of stereotypization or self-stereotypization. The review of domestic and international reports clearly demonstrates that gender disproportions are still significant on post-doctoral and professorial levels. It generates a certain discrepancy between neoliberal theory of equal access and academic practice. The specific character of an educational paradox and seeming equality is accurately described by A.S. Aronsson, who studied careers of Japanese women. She highlights that "The illusory nature of neoliberalism - akin to the paradox of Max Weber »iron cage « - can be understood as a form of chimera. The very system that made these women believe they had endless possibilities and freedoms ensnared them with false promises" 46 .The above reflection, although not very optimistic, wonderfully describes a professional ambiguity (and uncertainty) of a position held by female academics on the university career ladder. A particular dualism of the message and indeterminate complexity of roles generate identity confusion, which can raise even more barriers for women, within and outside an organization. This particularly ambiguous problem inspired me to see a certain analogy with psychoanalytic thought. Making an effective change in disadvantageous and destructive phenomena requires insight into the psychic structure of the organism (in this case a University). Therefore, in order to broaden (self)perception in the name of discovery of the truth and rejection of an illusion, one has to become aware of the repressed and the unconscious.

43 A. Gromkowska-Melosik, Z. Melosik, Tożsamość w społeczeństwie wspótczesnym: popkulturowe (re)interpretacje, Kraków 2012, p. 84.

${ }^{44}$ A. Titkow, Tożsamość polskich kobiet. Ciagłość, zmiana, konteksty, Warszawa 2007, s. 272.

45 R. Morrison, H. Cooper-Thomas, Relationships in Organizations: A Work Psychology Perspective, New Zeland 2013, p. 155.

46 A.S. Aronsson, Career Women in Contemporary Japan: Pursuing Identities, Fashioning Lives, New York 2015, p. 43. 
I hope that my paper will contribute in some modest way to the exposure of certain facts, often undisclosed, depreciated and hidden deeply on the bottom of the social (un)conscious.

\section{BIBLIOGRAPHY}

Aronsson A.S., Career Women in Contemporary Japan: Pursuing Identities, Fashioning Lives, New York 2015.

Betz N.E., Hackett G., Career Self-Efficacy Theory: Back to the Future, Journal of Career Assessment, 2006, 14(1).

Bourdieu P., Męska dominacja, Warszawa 2004.

Brannon L., Psychologia rodzaju. Kobiety i mężczyźni: podobni czy różni, Gdańsk 2002.

Brown S.D., Lent R.W., Career Development and Counseling: Putting Theory and Research to Work, New Jersey 2013, https://books.google.pl/books?id=3AEnri4bwWAC\&pg= PT196\&dq=women+career+or+motherhood\&hl=pl\&sa=X\&ved=0CCQQ6AEwATgU ahUKEwivztnS6_vGAhVCCdsKHSSYAUE\#v=snippet\&q=\%20U.S.\%20Census\&f $=$ fal se, [Accessed: 27.07.2015].

Heward Ch., Women and Careers in Higher Education: What is the Problem? Christine Hewards, [in:] Breaking Boundaries: Women in Higher Education, eds. L. Morley, V. Walsh, London 2005.

Cook E.P., Heppner M.J., O'Brien K.M., Career development of women of color and white women: Assumptions, conceptualizations, and interventions from an ecological perspective, The Career Development Quarterly, 2002, 20.

Cybal-Michalska A., Młodzież akademicka a kariera zawodowa, Kraków 2013.

Derra A., KOBIETY (W) NAUCE: Problem ptci we wspótczesnej filozofii nauki i w praktyce badawczej, Warszawa 2013.

Gregory S.T., Black Women in the Academy: The Secrets to Success and Achievement, Lanham 1999.

Gromkowska-Melosik A., Edukacja, kultura i rekonstrukcje kobiecości we wspótczesnej Japonii (ucieczka do/od równości $i$ wolności), [in:] Problemy nierówności społecznej w teorii i praktyce edukacyjnej, eds. A. Gromkowska-Melosik, T. Gmerek, Kraków 2008.

Gromkowska-Melosik A., Indywidualizm, liberalna edukacja i paradoksy emancypacji kobiet, [in:] Problemy nierówności społecznej w teorii i praktyce edukacyjnej, eds. A. Gromkowska-Melosik, T. Gmerek, Kraków 2008.

Gromkowska-Melosik A., Edukacja i (nie)równość społeczna kobiet: studium dynamiki dostępu, Kraków 2011.

Gromkowska-Melosik A., Melosik Z., Tożsamość w społeczeństwie wspótczesnym: popkulturowe (re)interpretacje, Kraków 2012.

Hackett G., Betz N.E., A Self-Efficacy Approach to the Career Development of Women, Journal of Vocational Behavior, 1981, 18.

Hannah E., Vethamany-Globus S., Pau L., Women in the Canadian Academic Tundra: Challenging the Chill, Canada 2002.

Judzińska A., Womanhood-contemporary paradoxes of equality and exclusion, Journal of Gender and Power, 2014, 2(2).

Leeb C., Working Class Women in Elite Academia: A Philosophical Inquiry, Brussels 2004. 
McWhirter E.H., Perceived Barriers to Education and Career: Ethnic and Gender Differences, Journal of Vocational Behavior, 1997, 50.

Melosik Z., Uniwersytet i społeczeństwo: dyskursy wolności, wiedzy i władzy, Kraków 2009.

Młodożeniec M., Knapińska A., Czy nauka wciąż ma męska płeć? Udział kobiet w nauce, NAUKA, 2013, 2.

Morrison R., Cooper-Thomas H., Relationships in Organizations: A Work Psychology Perspective, New Zeland 2013.

Myrdal A., Klein V., Women's Two Roles: Home and Work, London 1956.

Patton W., McMahon M., Career Development and Systems Theory: Connecting Theory and Practice, Rotterdam-Boston-Taipei 2014.

Program Międzynarodowej Oceny Umiejętności Uczniów OECD PISA, PISA 2012, http://www.ibe.edu.pl/images/prasa/PISA-2012-raport_krajowy.pdf, [Accessed: 26.07.2015].

Rosser S.V., The Science Glass Ceiling: Academic Women Scientists and the Struggle to Succeed, London 2004.

She Figures 2012, Statistics and Indicators and Innovation, Gender in Research, http:/ / ec.europa.eu/research/science-society/document_library/pdf_06/shefigures-2012_en.pdf, [Accessed: 27.07.2015].

Sulik M., Kobiety w nauce. Podmiotowe i społeczno-kulturowe uwarunkowania, Katowice 2010.

The ABC of Gender Equality in Education Aptitude, Behaviour, Confidence, OECD 2015, http://www.oecd.org/pisa/keyfindings/pisa-2012-results-gender-eng.pdf, [Accessed: 26.07.2015].

Titkow A., Tożsamość polskich kobiet. Ciagłość, zmiana, konteksty, Warszawa 2007.

Yost E., Handley D.M., Cotten S.R., Winstead V., Understanding the Links between Mentoring and Self-Efficacy in the New Generation of Women STEM Scholars, [in:] Women in Engineering, Science and Technology: Education and Career Challenges, eds. A. Cater-Steel, E. Cater, New York 2010.

Zamojska E., Równość w kontekstach edukacyjnych. Wybrane aspekty równości w polskich i czeskich podręcznikach szkolnych, Poznań 2010. 